\title{
Quantifying the Level of Awareness on Brand Extension using Index as the Tool
}

\author{
R. Rajkumar, Lj. Chaarlas
}

\begin{abstract}
Marketing Management, one of the major functions of the business, facilitates the strongest affiliation of business to the customer through the delivery of what the customer likes, wants, demands and cherish. The brand delivers a clear message about its product and the company, confirms the credibility, motivates the consumer, builds up and concretes the loyalty. Brand Extension has been a commonly accepted marketing strategy used to break the entry barriers between product categories through the carryover of a brand's reputation. It is important, hence, to study how strong the brands which have already extended have, in reality, grown by studying the level of awareness among the consumers. Hence, there arises a need to understand the reach of brand extension based on the brand awareness of the market under the title, "Quantifying the Level of Awareness on Brand Extension using Index as the Tool". A renowned/successful brand helps an organization to launch products in new categories more easily. Reduction of the risk perceived by customers, reduction in the promotional expenditure and reduction of the cost of developing a new brand are the benefits of Brand Extension. The reach of Brand Extension has been found to be satisfactory and the level of awareness on Foreign Brands. Brand Extension should be used to improve the CSR capability of the company besides being to enhance the marketing and the profitability of the company.
\end{abstract}

Key Words: Brand Extension, Brand Awareness, Brand Awareness Index, Foreign Brands, Electronic Brands.

\section{INTRODUCTION AND JUSTIFICATION}

The human life in this universe has undergone, from the time immemorial, innumerable changes that are immeasurable and unimaginable. Though many factors and forces can be traced to be responsible for these changes, business-the most splendid invention of human race is the only one that could account for the major share and a vital role.

Though Marketing Management is one of the functions of business, it is the only function that carries the business to the customers-the most important among stakeholders of the business.

It is considered to be the heart and soul of the business. It facilitates the strongest affiliation of business to the customer through the delivery of what the customer likes, wants,

Revised Manuscript Received on July 22, 2019.

Dr. R. RAJKUMAR, Assistant Professor in Commerce, St. Joseph's College of Arts and Science (Autonomous), Cuddalore, Tamil Nadu, India.

Dr. LJ. CHAARLAS, Head and Associate Professor in Commerce, St. Joseph's College (Autonomous), Tiruchirappalli, Tamil Nadu, India. demands and cherish. Every time the consumer buys, a foundation stone for the existence and growth is laid.

The brand is the window through which the customer looks into the business. The customers evaluate the business mainly through the brands it extends to them. The size and quality of the market and market share are the reflection of the brand image in the minds of the consumers. Their association and interaction with the business depend on the brand image.

The brand delivers a clear message about its product and the company, confirms the credibility, motivates the consumer, builds up and concretes the loyalty. Now a days, many companies have started to add their brands to their balance sheet to improve their perceived value.

Corporates adapt different strategy related to brands such as 'brand creation', 'brand positioning', 'brand equity', 'brand image', 'brand personality' and 'brand extension' to exist, grow and compete in the market place.

Brand Extension has been a commonly accepted marketing strategy used to break the entry barriers between product categories through the carryover of a brand's reputation.

The market has been witnessing extension of brands by the corporate world to survive and grow by gaining an edge over those of their competitors. The success of extensions of brands depends on the level of awareness of the consumers on them. If the level of awareness of the consumers on the extension is strong and clear the brand survives or else, it disappears from the market and the minds of the consumers like a fad.

It is important, hence, to study how strong the brands which have already extended have, in reality, grown by studying the level of awareness among the consumers.

Hence, there arises a need to understand the reach of brand extension based on the brand awareness of the market under the title, "QUANTIFYING THE LEVEL OF AWARENESS ON BRAND EXTENSION USING INDEX AS THE TOOL".

\section{OBJECTIVES OF THE STUDY}

A study on "Quantifying the Level of Awareness on Brand Extension using Index as the Tool" has been carried out with the following overall and specific objectives.

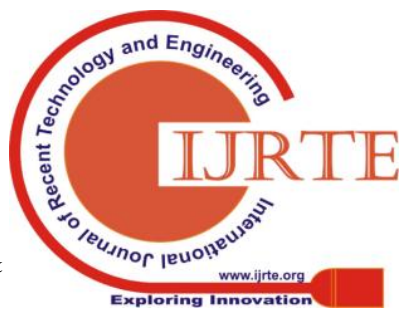




\section{Overall Objectives}

1. To study the reach of Brand Extension based on the strength of Brand Awareness.

2. To develop an Awareness Index and to measure the level of awareness with the awareness index.

\section{Specific Objectives}

1. To study the reach of brand extension of Foreign Brands.

2. To study the reach of brand-extended products classified as IT and Communication products, Entertainment products and Domestic Utility products.

3. To make the comparison of the reach of brand-extended products classified as IT and Communication products, Entertainment products and Domestic Utility products.

4. To measure the level of awareness on Foreign Brands with the awareness index.

5. To make a comparison of the reach of brand-extended products classified as IT and Communication products, Entertainment products and Domestic Utility products with the awareness index.

\section{HYPOTHESES OF THE STUDY}

A study on "Quantifying the Level of Awareness on Brand Extension using Index as the Tool" has been carried out with the following null hypotheses.

\section{Null Hypotheses}

1. There is no significant difference between gender, UG qualification, total monthly family income, total monthly family expenses, districts of the respondents and their overall awareness among on extended brands of Foreign.

2. There is no significant difference between gender, UG qualification, total monthly family income, total monthly family expenses, districts of the respondents and their overall awareness among the products of the extended brands of Foreign.

3. There is no significant association between age of the respondents and their overall awareness among on extended brands of Foreign.

4. There is no significant association between age of the respondents and their overall awareness among the products of the extended brands of Foreign.

\section{SCOPE AND DELIMITATIONS OF THE STUDY}

The Study was confined to the students who are pursuing the degree of Master of Business Administration offered by the B-Schools of Various Districts located in Tiruchirappalli Region of Anna University, Chennai.

The Study analyses and evaluates the reach of Brand Extension based on the strength of brand awareness and the brand awareness index among the B-School students.
The Top 5 Foreign Brands in 2011 have been taken for the study. They are Intel, Apple, HP, Samsung and Canon among the foreign brands.

All the products of the selected 5 brands of Foreign [Intel, Apple, HP, Samsung and Canon] are taken into consideration for the study.

The data has been conducted for a period of six months from June 2013 to December 2013.

This study has been designed to be useful to the corporates while they decide to extend their brands, to the researchers in marketing management, to the consumers.

\section{SOCIAL RELEVANCE OF THE STUDY}

The findings and suggestions of this study can be used by the marketers to influence the behaviour of the consumers while making appropriate decisions on:

1. the amount of promotional expenditure,

2. the cost of developing a new brand,

3 . reduction of risk perceived by the customers and

4. making easy the process of perceptive by the consumers.

\section{LIMITATIONS OF THE STUDY}

The study may suffer from the following limitations.

The study was confined only to the students of B-Schools of Tiruchirappalli region of AnnaUniversity, Chennai alone, which may restrict the universal application of the result.

The study has been carried out only to the Top 5 Foreign electronic brands of 2011.

The data have been collected during the period of June 2013 to December 2013. Hence the result may vary when compared with that of any period other than the study period.

The study aims at quantifying the qualitative responses of the respondents. Hence, the result depends on the genuineness of the response.

The Findings, Suggestions, and Conclusion will be applicable only to the B-Schools students of Tiruchirappalli region, Anna University, Chennai and may not apply among B-School students outside of any other degree of any college in other regions.

\section{METHODOLOGY}

The methodology of this study consists of the research design, developed on the sound principles of research. The research design consists of:

I. Universe,

II. Sample,

III. Data,

IV. Analysis,

V. Statistical tools used,

VI. Steps for developing the Awareness Index.

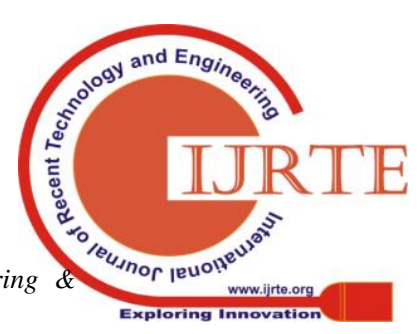




\section{UNIVERSE OF THE STUDY}

The Universe of this study is the students of B-Schools, Tiruchirappalli Region, Anna University, Chennai.

The list of Various Districts located in Tiruchirappalli Region of Anna University, Chennai has been presented in Table -01 .

TABLE - 01

DISTRICTS OF TIRUCHIRAPPALLI REGION, ANNAUNIVERSITY, CHENNAI

\begin{tabular}{|l|l|}
\hline $\mathbf{1}$ & DISTRICTS \\
\hline 1. & ARIYALUR \\
\hline 2. & CUDDALORE \\
\hline 3. & NAGAPPATTINAM \\
\hline 4. & PERAMBALUR \\
\hline 5. & PUDUKKOTTAI \\
\hline 6. & TANJAVUR \\
\hline 7. & TIRUCHIRAPPALLI \\
\hline 8. & TIRUVARUR \\
\hline
\end{tabular}

Source: http://www.annauniv.edw/cail3b/Region\%20II.html accessed on 09.02.2013 at $11.20 \mathrm{Hr}$.

The list of B-Schools located in Various Districts of Tiruchirappalli Region, Anna University, has been presented in Table -02 .

TABLE - 02

\section{LIST OF B-SCHOOLS IN THE DISTRICTS IN TIRUCHIRAPPALLI REGION, ANNAUNIVERSITY}

\begin{tabular}{|c|l|l|}
\hline $\begin{array}{c}\text { S. } \\
\text { No. }\end{array}$ & \multicolumn{1}{|c|}{ DISTRICTS } & \multicolumn{1}{|c|}{ B - SCHOOLS } \\
\hline 1 & ARIYALUR & \multicolumn{1}{|c|}{ NIL } \\
\hline 2 & CUDDALORE & \multicolumn{1}{|c|}{ NIL } \\
\hline 3 & NAGAPPATTINAM & $\begin{array}{l}\text { 1. Dhanalakshmi Srinivasan } \\
\text { Institute of Management }\end{array}$ \\
\hline 4 & PERAMBALUR & $\begin{array}{l}\text { 2. Holy Angels School of } \\
\text { Business } \\
\text { Roever Institute of } \\
\text { Management }\end{array}$ \\
\hline 5 & PUDUKKOTTAI & $\begin{array}{l}\text { 1. Karpaga Vinayaga Institute } \\
\text { of Management } \\
\text { 2. Nalanda School of Business }\end{array}$ \\
\hline 6 & TANJAVUR & $\begin{array}{l}\text { 1. Gnanam School of } \\
\text { Business } \\
\text { 2. Swami Vivekananda } \\
\text { Institute of Management }\end{array}$ \\
\hline 7 & TIRUCHIRAPPALLI & $\begin{array}{l}\text { 1. Hallmark Business School } \\
\text { 2. M.A.M B - School } \\
\text { 3. R.V.S - K.V.K Institute of } \\
\text { Management Studies } \\
\text { 4. Shivani School of Business } \\
\text { Management }\end{array}$ \\
\hline 8 & TIRUVARUR & $\begin{array}{l}\text { A.R.J Institute of } \\
\text { Management Studies }\end{array}$ \\
\hline
\end{tabular}

Source: $\quad$ The list of $B$-Schools were taken from the links of the respective Districts of Tiruchirappalli region.
Number of students pursuing Master of Business Administration in the B-Schools in Tiruchirappalli Region, collected through personal interviews with the official concerned has been presented in Table -03 .

TABLE - 03

NUMBER OF STUDENTS OF B-SCHOOLS

\begin{tabular}{|c|c|c|c|c|c|c|}
\hline \multirow{2}{*}{$\begin{array}{l}\text { S. } \\
\text { No. }\end{array}$} & \multirow[b]{2}{*}{ District } & \multirow[b]{2}{*}{ B - Schools } & \multicolumn{3}{|c|}{ No. of Students } & \multirow{2}{*}{$\begin{array}{l}\text { No. of } \\
\text { Students } \\
\text { in Each } \\
\text { District }\end{array}$} \\
\hline & & & Boys & Girls & Total & \\
\hline 1. & ARIYALUR & $\mathrm{NIL}$ & \multicolumn{3}{|c|}{ NIL } & NIL \\
\hline 2. & CUDDALORE & NIL & \multirow{2}{*}{\multicolumn{3}{|c|}{ NIL }} & NIL \\
\hline 3. & NAGAPPATTINAM & NIL & & & & NIL \\
\hline \multirow{3}{*}{4.} & \multirow{3}{*}{ PERAMBALUR } & $\begin{array}{c}\text { Dhanalakshmi } \\
\text { Srinivasan Institute of } \\
\text { Management } \\
\end{array}$ & 18 & 12 & 30 & \multirow{3}{*}{222} \\
\hline & & $\begin{array}{l}\text { Holy Angels School of } \\
\text { Business }\end{array}$ & 32 & 20 & 52 & \\
\hline & & $\begin{array}{l}\text { Roever Institute of } \\
\text { Management }\end{array}$ & 95 & 45 & 140 & \\
\hline \multirow{2}{*}{5.} & \multirow{2}{*}{ PUDUKKOTTAI } & $\begin{array}{l}\text { Karpaga Vinayaga } \\
\text { Institute of } \\
\text { Management }\end{array}$ & 78 & 92 & 170 & \multirow{2}{*}{310} \\
\hline & & $\begin{array}{c}\text { Nalanda School of } \\
\text { Business }\end{array}$ & 60 & 80 & 140 & \\
\hline \multirow[b]{2}{*}{6.} & \multirow[b]{2}{*}{ TANJAVUR } & $\begin{array}{l}\text { Gnanam School of } \\
\text { Business }\end{array}$ & 90 & 38 & 128 & \multirow[b]{2}{*}{146} \\
\hline & & $\begin{array}{l}\text { Swami Vivekananda } \\
\text { Institute of } \\
\text { Management } \\
\end{array}$ & 7 & 11 & 18 & \\
\hline \multirow{4}{*}{7.} & \multirow{4}{*}{ TIRUCHIRAPPALLI } & $\begin{array}{l}\text { Hallmark Business } \\
\text { School }\end{array}$ & 96 & 48 & 144 & \multirow{4}{*}{402} \\
\hline & & M.A.M B - School & 28 & 30 & 58 & \\
\hline & & $\begin{array}{c}\text { R.V.S - K.V.K } \\
\text { Institute of } \\
\text { Management Studies } \\
\end{array}$ & 62 & 38 & 100 & \\
\hline & & $\begin{array}{c}\text { Shivani School of } \\
\text { Business Management }\end{array}$ & 48 & 52 & 100 & \\
\hline \multirow[t]{2}{*}{8.} & TIRUVARUR & $\begin{array}{l}\text { A.R.J Institute of } \\
\text { Management Studies }\end{array}$ & 27 & 76 & 103 & 103 \\
\hline & & \multicolumn{4}{|c|}{ TOTAL UNIVERSE } & 1183 \\
\hline
\end{tabular}

Source: Field Data

All the $\mathbf{1 1 8 3}$ students have been considered as the universe of the study.

\section{SAMPLE}

For the universe 1183, the number of respondents who formed the sample [60\% of the Universe] is 711 .

No. of respondents $=\frac{1183}{100} \times 60 \quad=711$

Source: Field Data

The 711 Students [60\% of the Universe] have been selected as the sample through Stratified Proportionate Random Sampling Method. This is highlighted in the Table -04 .

TABLE - 04

DISTRIBUTION OF THE SAMPLE

\begin{tabular}{|c|c|c|c|c|c|c|}
\hline \multirow[b]{2}{*}{1} & \multirow[b]{2}{*}{ Districts } & \multirow[b]{2}{*}{ B - Schools } & \multicolumn{3}{|c|}{ Sample } & \multirow{2}{*}{$\begin{array}{c}\text { Total of } \\
\text { Each } \\
\text { District }\end{array}$} \\
\hline & & & Boys & Girls & Total & \\
\hline 1. & ARIYALUR & NIL & \multicolumn{3}{|c|}{ NIL } & NIL \\
\hline 2. & CUDDALORE & NIL & \multirow{2}{*}{\multicolumn{3}{|c|}{$\begin{array}{l}\text { NIL } \\
\text { NIL }\end{array}$}} & NIL \\
\hline 3. & NAGAPPATTINAM & NIL & & & & NIL \\
\hline \multirow[t]{2}{*}{4.} & \multirow[t]{2}{*}{ PERAMBALUR } & $\begin{array}{c}\text { Dhanalakshmi } \\
\text { Srinivasan } \\
\text { Institute of } \\
\text { Management }\end{array}$ & 11 & 7 & 18 & \multirow[t]{2}{*}{133} \\
\hline & & $\begin{array}{l}\text { Holy Angels } \\
\text { School of } \\
\text { Business }\end{array}$ & 19 & 12 & 31 & \\
\hline
\end{tabular}


Quantifying the Level of Awareness on Brand Extension using Index as the Tool

\begin{tabular}{|c|c|c|c|c|c|c|}
\hline \multirow{3}{*}{1} & \multirow{3}{*}{ Districts } & \multirow[b]{2}{*}{ B - Schools } & \multicolumn{3}{|c|}{ Sample } & \multirow{3}{*}{$\begin{array}{c}\text { Total of } \\
\text { Each } \\
\text { District }\end{array}$} \\
\hline & & & Boys & Girls & Total & \\
\hline & & $\begin{array}{l}\text { Roever Institute } \\
\text { of Management }\end{array}$ & 57 & 27 & 84 & \\
\hline \multirow{2}{*}{5.} & \multirow{2}{*}{ PUDUKKOTTAI } & $\begin{array}{c}\text { Karpaga } \\
\text { Vinayaga Institute } \\
\text { of Management }\end{array}$ & 47 & 55 & 102 & \multirow{2}{*}{186} \\
\hline & & $\begin{array}{c}\text { Nalanda School } \\
\text { of Business }\end{array}$ & 36 & 48 & 84 & \\
\hline \multirow[b]{2}{*}{6.} & \multirow[b]{2}{*}{ TANJAVUR } & $\begin{array}{c}\text { Gnanam School } \\
\text { of Business }\end{array}$ & 54 & 23 & 77 & \multirow[b]{2}{*}{88} \\
\hline & & $\begin{array}{c}\text { Swami } \\
\text { Vivekananda } \\
\text { Institute of } \\
\text { Management } \\
\end{array}$ & 4 & 7 & 11 & \\
\hline \multirow{4}{*}{7.} & \multirow{4}{*}{ TIRUCHIRAPPALLI } & $\begin{array}{c}\text { Hallmark } \\
\text { Business School } \\
\end{array}$ & 58 & 29 & 87 & \multirow{4}{*}{242} \\
\hline & & $\begin{array}{l}\text { M.A.M B - } \\
\text { School }\end{array}$ & 17 & 18 & 35 & \\
\hline & & $\begin{array}{l}\text { R.V.S - K.V.K } \\
\text { Institute of } \\
\text { Management } \\
\text { Studies } \\
\end{array}$ & 37 & 23 & 60 & \\
\hline & & $\begin{array}{c}\text { Shivani School of } \\
\text { Business } \\
\text { Management } \\
\end{array}$ & 29 & 31 & 60 & \\
\hline \multirow[t]{2}{*}{8.} & TIRUVARUR & $\begin{array}{l}\text { A.R.J Institute of } \\
\text { Management } \\
\text { Studies } \\
\end{array}$ & 16 & 46 & 62 & 62 \\
\hline & \multicolumn{5}{|c|}{$\begin{array}{l}\text { TOTAL SIZE OF THE SAMPLE } \\
\end{array}$} & 711 \\
\hline
\end{tabular}

Source: Field Data.

\section{DATA}

The study is based on both primary and secondary data collected.

\section{Primary Data}

The Primary data have been collected through the following Steps:

\section{Stage - 1: SELECTING THE TOP 50 FOREIGN BRANDS OF 2011}

The Top 50 Foreign brands of 2011 have been presented in Table -05 .

TABLE - 05

TOP 50 FOREIGN BRANDS OF 2011

\begin{tabular}{|c|c|c|}
\hline Rank & Brand Name & Category \\
\hline 1. & & Beverages \\
\hline 2. & $\underline{\bar{E}}$ & Business Services \\
\hline 3. & ft & Computer Software \\
\hline 4. & & Internet Services \\
\hline 5. & & Diversified \\
\hline 6. & & Restaurants \\
\hline 7. & & Electronics \\
\hline 8. & & Electronics \\
\hline 9. & & Media \\
\hline 10. & & Electronics \\
\hline
\end{tabular}

\begin{tabular}{|c|c|c|}
\hline Rank & Brand Name & Category \\
\hline 11. & & Automotive \\
\hline 12. & & Automotive \\
\hline 13. & & Business Services \\
\hline 14. & NGKCIA & Electronics \\
\hline 15. & & Automotive \\
\hline 16. & & FMCG \\
\hline 17. & & Electronics \\
\hline 18. & & Luxury \\
\hline 19. & HONNDA & Automotive \\
\hline 20. & ACLE & Business Services \\
\hline 21. & & Apparel \\
\hline 22. & & Beverages \\
\hline 23. & & Financial Services \\
\hline 24. & & Business Services \\
\hline 25. & & Sporting Goods \\
\hline 26. & & Internet Services \\
\hline 27. & & Transportation \\
\hline 28. & & Financial Services \\
\hline 29. & & Alcohol \\
\hline 30. & & Beverages \\
\hline 31. & & Home Furnishings \\
\hline 32. & $\mathrm{HSBC}$ & Financial Services \\
\hline 33. & Calloli & Electronics \\
\hline 34. & Ylologes: & FMCG \\
\hline 35. & SONY & Electronics \\
\hline 36. & & Internet Services \\
\hline
\end{tabular}

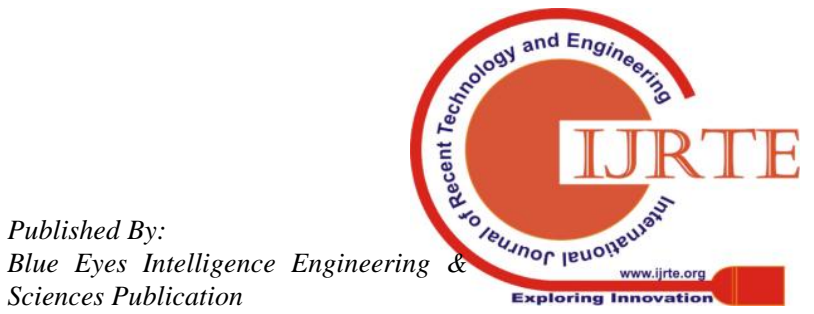




\begin{tabular}{|c|c|c|}
\hline Rank & Brand Name & Category \\
\hline 37. & & Media \\
\hline 38. & goceman & Financial Services \\
\hline 39. & $\mathrm{G} \cup \mathrm{C} \mathbf{C}$ & Luxury \\
\hline 40. & L'OREAL" & FMCG \\
\hline 41. & PHILIPS & Electronics \\
\hline 42. & & Financial Services \\
\hline 43. & & Electronics \\
\hline 44. & & Apparel \\
\hline 45. & & Business Services \\
\hline 46. & SEMENS & Diversified \\
\hline 47. & & Automotive \\
\hline 48. & (Nintendo & Electronics \\
\hline 49. & Sieinz) & FMCG \\
\hline 50. & & Automotive \\
\hline
\end{tabular}

Source: http://www.interbrand.com/en/best-global-brands/previous-years/ best-global-brands-2011.aspx accessed on 12.07.2012 at 14.25Hrs.

\section{Stage - 2: SELECTING FOREIGN ELECTRONIC BRANDS OF 2011}

From the Top 50 Foreign brands of 2011, the Top Foreign electronic brands of 2011 have been listed and shown in Table $-06$.

TABLE - 06

\section{TOP FOREIGN ELECTRONIC BRANDS OF 2011}

\begin{tabular}{|c|l|l|}
\hline $\begin{array}{c}\text { S. } \\
\text { No. }\end{array}$ & Rank & Brands \\
\hline 1. & 7 & Intel \\
\hline 2. & 8 & Apple \\
\hline 3. & 10 & HP \\
\hline 4. & 14 & Nokia \\
\hline 5. & 17 & Samsung \\
\hline 6. & 33 & Canon \\
\hline 7. & 35 & Sony \\
\hline 8. & 41 & Philips \\
\hline 9. & 43 & Dell \\
\hline 10. & 48 & Nintendo \\
\hline
\end{tabular}

Source: Field Data.

Stage-3: SELECTING THE TOP 5 FOREIGN ELECTRONIC BRANDS OF 2011

TABLE - 07

TOP 5 FOREIGN ELECTRONIC BRANDS OF 2011

\begin{tabular}{|l|l|}
\hline S. No. & Brands \\
\hline 1. & Intel \\
\hline 2. & Apple \\
\hline 3. & HP \\
\hline 4. & Nokia \\
\hline 5. & Samsung \\
\hline
\end{tabular}

Source: http://www.interbrand.com/en/best-global-brands/previous-years/ best-global-brands-2011.aspx accessed on 12.07.2012 at 14.25Hrs.

\section{Stage - 8: SELECTING THE LIST OF ELECTRONIC PRODUCTS OF TOP 5 FOREIGN BRANDS}

The electronic products of chosen foreign brands are listed in the Table -08 .

TABLE - 08

PRODUCTS OF FOREIGN ELECTRONIC BRANDS

\begin{tabular}{|l|l|}
\hline Brands & Products \\
\hline Intel & Net books \\
& Television \\
Smart phones \\
Tablets \\
& Desktops \\
& Laptops \\
\hline Apple & Laptops \\
& Desktops \\
& I Pad \\
& I Pod \\
& I Phone \\
& Televisions \\
\hline HP & Laptops \\
& Desktops \\
& Printers \\
& Calculators \\
& Home theatre \\
& Photo frames \\
& Projectors \\
& Televisions \\
\hline Nokia & Mobile phones [No Extend Products] \\
\hline Samsung & Mobile phones \\
& Tablets \\
& Television \\
& DVD player \\
& Home theatre \\
& Camera \\
& Camcorder \\
& Refrigerator \\
& Air conditioner \\
& Washing machine \\
& Microwave oven \\
& Dish washer \\
& Printers \\
& Desktops \\
& Laptops \\
& Memory cards \\
\hline & wasten from \\
&
\end{tabular}

Source: The list of Products was taken from the Websites of the respective Brands.

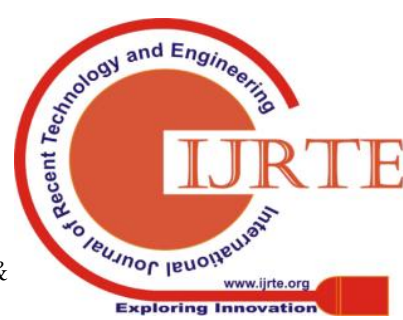


Since the brand NOKIA did not extend its Products. The researcher has selected the next electronic brand CANON which comes sixth in the rank. Hence, the Top 5 foreign brands of 2011 taken for the study includes brand CANON and the new list of Top 5 Foreign brands of 2011 is shown in the Table -09 .

TABLE - 09

REVISED TOP 5 FOREIGN ELECTRONIC BRANDS OF 2011

\begin{tabular}{|c|c|}
\hline S. No. & Brands \\
\hline 1. & Intel \\
\hline 2. & Apple \\
\hline 3. & HP \\
\hline 4. & Samsung \\
\hline 5. & Canon \\
\hline
\end{tabular}

Source:

http://www.interbrand.com/en/best-global-brands/previous-years/bestglobal-brands-2011.aspx accessed on 12.07.2012 at 14.25Hrs.

The electronic products of chosen revised foreign brands are listed in the Table -10 .

TABLE - 10

PRODUCTS OF REVISED FOREIGN ELECTRONIC BRANDS

\begin{tabular}{|c|c|}
\hline Brands & Products \\
\hline Intel & $\begin{array}{l}\text { Net books } \\
\text { Television } \\
\text { Smart phones } \\
\text { Tablets } \\
\text { Desktops } \\
\text { Laptops }\end{array}$ \\
\hline Apple & $\begin{array}{l}\text { Laptops } \\
\text { Desktops } \\
\text { I Pad } \\
\text { I Pod } \\
\text { I Phone } \\
\text { Televisions } \\
\end{array}$ \\
\hline HP & $\begin{array}{l}\text { Laptops } \\
\text { Desktops } \\
\text { Printers } \\
\text { Calculators } \\
\text { Home theatre } \\
\text { Photo frames } \\
\text { Projectors } \\
\text { Televisions }\end{array}$ \\
\hline Samsung & $\begin{array}{l}\text { Mobile phones } \\
\text { Tablets } \\
\text { Television } \\
\text { DVD player } \\
\text { Home theatre } \\
\text { Camera } \\
\text { Camcorder } \\
\text { Refrigerator } \\
\text { Air conditioner } \\
\text { Washing machine } \\
\text { Microwave oven } \\
\text { Dish washer } \\
\text { Printers } \\
\text { Desktops } \\
\text { Laptops } \\
\text { Memory cards }\end{array}$ \\
\hline Canon & $\begin{array}{l}\text { Camera } \\
\text { Camcorder } \\
\text { Projectors } \\
\text { Scanners }\end{array}$ \\
\hline
\end{tabular}

\begin{tabular}{|l|l|}
\hline Brands & Products \\
\hline & $\begin{array}{l}\text { Fax machine } \\
\text { Printers }\end{array}$ \\
\hline
\end{tabular}

Source: The list of Products was taken from the Websites of the respective Brands.

\section{CONSTRUCTION OF THE TOOL - QUESTIONNAIRE}

The questionnaire was framed with a [25x10] matrix, products in rows and Brands in columns to test the reach of brand extension based on the strength of brand awareness and the Awareness Index among the B-Schools Students.

The respondents were requested to write the numbers of the options that indicate the strength of their awareness on the availability/non-availability of the Products. The responses were in the form of numbers ranging from 1 to 5 , for

1 - Very Sure, its available,

2 - Sure, its available,

3 - Doubtful,

4 - Sure, its not available,

5 - Very Sure, its not available.

Note: These numbers, $1-5$, are the numbers of the options and not the numbers of the Likert Scale.

The respondents were requested not to leave any cell un-numbered.

The Demographic Profile of the respondents contains questions on Sex, Age [in completed years], Educational Qualification [UG], Total Monthly Family Income and Total Monthly Family Expenses.

\section{Secondary Data}

The secondary data were collected from Books, Journals, databases like PROQUEST, SCOPUS and SSRN and Google searched Websites were used to collect review of literature and other concepts for the study.

\section{STATISTICAL TOOLS USED}

The researcher has applied relevant statistical tools such as Descriptive Analysis, 'T'-Test, 'F'-Test and Chi-Square to analyze the data collected.

\section{DEVELOPMENT OF THE AWARENESS INDEX}

An Index that reflects the level of correct awareness on products of extended brands has been developed using the following formula and with the following steps.

$$
\text { Awareness Index }=\frac{\text { Weighted Actual Correct Awareness }}{\text { Weighted Ideal Correct Awareness }} \times 100
$$

\section{STEP - I}

Computing the weighted actual correct awareness is the sum of,

a] Number of respondents choosing the option 'very sure' $x$ $5=\mathrm{xxx}$

b] Number of respondents choosing the option 'Sure' $\mathrm{x} 4=$ $\mathrm{XXX}$

Total of $[a+b]=\mathbf{x x x}$ 


\section{STEP - II}

Computing the weighted Ideal correct awareness is,

Total number of respondents [711] $\times 5=\mathbf{3 5 5 5}$

Note: The Ideal Correct Awareness is based on the presumption that all the respondents have got the perfect awareness and have marked 'Very sure' as their choice for which the weighted ascertained in this study is ' 5 '.

\section{STEP - III}

Computing the Awareness Index

\section{STEP - IV}

Ranking the products in each brand according to the Awareness Index

\section{STEP - V}

Ranking the brands according to the Awareness Index

\section{REVIEW OF RELATED LITERATURE}

A study entitled, "An examination of the effects of perceived difficulty of manufacturing the extension product on brand extension attitudes" by Babu John Mariadoss, Raj Echambadi, Mark J. Arnold \& Vishal Bindroo (2010), examines the relationship between extension difficulty, defined as the perceived difficulty of manufacturing the extension product, and attitudes toward brand extensions. The study suggests that the relationship between extension difficulty and extension attitudes may be far more complex than a simple linear relationship. Based on theoretical evidence drawn from the concept of evaluation difficulty, the study suggests that the relationship between extension difficulty and extension attitudes is best modeled as a curvilinear (inverted U-shaped) relationship.

The article entitled (2005), "Brand-Extension Price Premiums: The Effects of Perceived Fit and Extension Product Category Risk" by Devon Del Vecchio and Daniel C. Smith, investigates the brand extension price premiums accrue in part due to the ability of a known brand to reduce the perceived risk customers experience in making purchase decisions. The study found that brand-extension price premiums are positively related to the perceived fit between the brand and the extension category. However, this relationship varies considerably depending on the levels of financial and social risk associated with the extension product category.

A study entitled "The Effects of Price on Brand Extension Evaluations: The Moderating Role of Extension Similarity" by Valerie A. Taylor and William O. Bearden (2002), explored the effects of price information on brand extension evaluations across different levels of similarity. Brand extension similarity is proposed as a moderator of the effects of price on brand extension perceived quality, perceived value, and purchase intentions. The result of the study indicate that a high-price introductory strategy used to suggest a high-quality product will likely be more effective for dissimilar extensions than similar extensions. The study suggests that a number of implications for new product pricing. Directions for subsequent research are offered as well.

A study entitled (2001), "The impact of brand extension introduction on choice" by Vnitha Swaminathan, Richard J. Fox, and Srinivas K. Reddy, examined the impact of a new brand extension introduction on choice in a behavioural context using national household scanner data involving multiple brand extensions. Particularly, the authors investigated the reciprocal impact of trial of successful and unsuccessful brand extensions on parent choice. The study found that the evidence for potential negative reciprocal effects of unsuccessful extensions. In addition, the study shows that experience with the parent brand has a significant impact on extension trial, but not on extension repeat.

"Effect of Inner and Social Dimensions of Brand Image on Consumer Attitude toward Brand Extension" by Catherine Viot, analysed the conceptual foundation to the perceived fit concept based on brand image. The study found that coherent brand extension with the personal or social dimension of brand image is better evaluated by consumer. The results of the study provide that a number of insights on consumer evaluation of brand extension.

\section{FINDINGS OF THE STUDY}

Results of the reach of extended brands

TABLE - 11

COMPARATIVE STATEMENT OF REACH OF FOREIGN BRANDS [ALL PRODUCTS]

\begin{tabular}{|c|c|c|c|c|c|c|c|c|c|}
\hline $\begin{array}{c}\text { S. } \\
\text { No }\end{array}$ & $\begin{array}{c}\text { Various } \\
\text { brand } \\
\text { awareness }\end{array}$ & Low & High & Min. & Max. & S.D & Median & Mean & $\begin{array}{c}\text { Mean } \\
\text { Rank }\end{array}$ \\
\hline 1. & Intel & $344(48.4 \%)$ & $367(51.6 \%)$ & 47 & 113 & $\begin{array}{c}12.53 \\
9\end{array}$ & 85.00 & 84.57 & 4 \\
\hline 2. & Apple & $339(47.7 \%)$ & $372(52.3 \%)$ & 48 & 118 & $\begin{array}{c}13.95 \\
7\end{array}$ & 90.00 & 89.69 & 1 \\
\hline 3. & HP & $343(48.2 \%)$ & $368(51.8 \%)$ & 49 & 105 & $\begin{array}{c}10.20 \\
8\end{array}$ & 84.00 & 83.70 & 5 \\
\hline 4. & Samsung & $374(52.6 \%)$ & $337(47.4 \%)$ & 61 & 110 & 8.892 & 89.00 & 89.13 & 2 \\
\hline 5. & Canon & $370(52 \%)$ & $341(48 \%)$ & 38 & 123 & $\begin{array}{c}16.98 \\
7\end{array}$ & 86.00 & 86.98 & 3 \\
\hline
\end{tabular}

Source: Field Data

It may concluded that, according to the overall mean value of awareness computed, 'Apple', 'Samsung' and 'Canon' have got the first three ranks respectively and hence, it could be presumed that the strength of awareness is very high for these brands.

'Intel' and 'HP' have got the last two ranks respectively and hence, it could be presumed that the strength of awareness is very low for these brands. 
TABLE - 12

COMPARATIVE STATEMENT OF REACH OF IT AND COMMUNICATION PRODUCTS [ALL BRANDS]

TABLE - 13

COMPARATIVE STATEMENT OF REACH OF ENTERTAINMENT PRODUCTS [ALL BRANDS]

\begin{tabular}{|c|c|c|c|c|c|c|c|c|c|}
\hline $\begin{array}{l}\text { S. } \\
\text { No }\end{array}$ & $\begin{array}{c}\text { Product } \\
\text { awarenes } \\
s\end{array}$ & Low & High & Min & Max. & S.D & $\begin{array}{c}\text { Media } \\
\mathrm{n}\end{array}$ & $\begin{array}{c}\text { Mea } \\
\text { n }\end{array}$ & $\begin{array}{c}\text { Mea } \\
\text { n } \\
\text { Rank }\end{array}$ \\
\hline 1. & $\begin{array}{l}\text { Net book / } \\
\text { Laptop }\end{array}$ & $\begin{array}{c}332(46.7 \% \\
)\end{array}$ & $\begin{array}{c}379(53.3 \% \\
)\end{array}$ & 23 & 50 & $\begin{array}{c}5.92 \\
6\end{array}$ & 41.00 & 40.73 & 1 \\
\hline 2. & $\begin{array}{l}\text { Mobile } \\
\text { Phone/I } \\
\text { Phone }\end{array}$ & $\begin{array}{c}352(49.5 \% \\
)\end{array}$ & $\begin{array}{c}359(50.5 \% \\
)\end{array}$ & 20 & 47 & $\begin{array}{c}5.23 \\
1\end{array}$ & 39.00 & 38.05 & 2 \\
\hline 3. & $\begin{array}{l}\text { Tablet/ I } \\
\text { Pad }\end{array}$ & $\begin{array}{c}415(58.4 \% \\
)\end{array}$ & $\begin{array}{c}296(41.6 \% \\
)\end{array}$ & 21 & 48 & $\begin{array}{c}5.76 \\
2\end{array}$ & 35.00 & 36.06 & 4 \\
\hline 4. & $\begin{array}{l}\text { Memory } \\
\text { Card }\end{array}$ & $\begin{array}{c}423(59.5 \% \\
)\end{array}$ & $\begin{array}{c}288(40.5 \% \\
)\end{array}$ & 14 & 50 & $\begin{array}{c}6.72 \\
8\end{array}$ & 34.00 & 34.75 & 5 \\
\hline 5. & Desktop & $370(52 \%)$ & $341(48 \%)$ & 20 & 50 & $\begin{array}{c}6.86 \\
6\end{array}$ & 36.00 & 36.23 & 3 \\
\hline 6. & $\begin{array}{l}\text { Printer / } \\
\text { Scanner / } \\
\text { Fax } \\
\text { Machine }\end{array}$ & $\begin{array}{c}355(49.9 \% \\
)\end{array}$ & $\begin{array}{c}356(50.1 \% \\
)\end{array}$ & 21 & 50 & $\begin{array}{c}7.26 \\
1\end{array}$ & 34.00 & 33.90 & 6 \\
\hline 7. & Calculator & $\begin{array}{c}369(51.9 \% \\
)\end{array}$ & $\begin{array}{c}342(48.1 \% \\
)\end{array}$ & 17 & 46 & $\begin{array}{c}7.27 \\
4\end{array}$ & 32.00 & 32.99 & 7 \\
\hline 8. & Projector & $456(64.1 \%$ & $255(35.9 \%$ & 18 & 48 & $\begin{array}{c}6.91 \\
2\end{array}$ & 30.00 & 31.06 & 8 \\
\hline
\end{tabular}

\begin{tabular}{|c|c|c|c|c|c|c|c|c|c|}
\hline $\begin{array}{l}\text { S. } \\
\text { No }\end{array}$ & $\begin{array}{c}\text { Product } \\
\text { awareness }\end{array}$ & Low & High & $\begin{array}{l}\text { Min } \\
\text {. }\end{array}$ & Max. & S.D & $\begin{array}{c}\text { Media } \\
\mathbf{n}\end{array}$ & $\begin{array}{c}\text { Mea } \\
\text { n }\end{array}$ & $\begin{array}{c}\text { Mea } \\
\text { n } \\
\text { Rank }\end{array}$ \\
\hline 1. & Television & $\begin{array}{c}321(45.1 \% \\
) \\
\end{array}$ & $\begin{array}{c}390(54.9 \% \\
)\end{array}$ & 21 & 46 & $\begin{array}{c}4.13 \\
7\end{array}$ & 36.00 & 35.42 & 1 \\
\hline 2. & I Pod & $\begin{array}{c}362(50.9 \% \\
)\end{array}$ & $\begin{array}{c}349(49.1 \% \\
)\end{array}$ & 15 & 50 & $\begin{array}{c}7.21 \\
2 \\
\end{array}$ & 34.00 & 34.53 & 2 \\
\hline 3. & $\begin{array}{l}\text { Home } \\
\text { Theatre }\end{array}$ & $\begin{array}{c}352(49.5 \% \\
)\end{array}$ & $\begin{array}{c}359(50.5 \% \\
)\end{array}$ & 22 & 43 & $\begin{array}{c}4.55 \\
9\end{array}$ & 34.00 & 33.29 & 3 \\
\hline 4. & $\begin{array}{l}\text { Photo } \\
\text { Frame }\end{array}$ & $\begin{array}{c}393(55.3 \% \\
) \\
\end{array}$ & $\begin{array}{c}318(44.7 \% \\
)\end{array}$ & 14 & 46 & $\begin{array}{c}7.67 \\
8 \\
\end{array}$ & 32.00 & 32.63 & 6 \\
\hline 5. & $\begin{array}{l}\text { DVD } \\
\text { Player }\end{array}$ & $\begin{array}{c}394(55.4 \% \\
) \\
\end{array}$ & $\begin{array}{c}317(44.6 \% \\
\quad \\
\end{array}$ & 18 & 46 & $\begin{array}{c}8.05 \\
8 \\
\end{array}$ & 31.00 & 32.84 & 5 \\
\hline 6. & Camera & $\begin{array}{c}408(57.4 \% \\
)\end{array}$ & $\begin{array}{c}303(42.6 \% \\
)\end{array}$ & 17 & 50 & $\begin{array}{c}7.50 \\
8\end{array}$ & 31.00 & 31.82 & 7 \\
\hline 7. & $\begin{array}{c}\text { Camcorde } \\
\mathrm{r}\end{array}$ & $\begin{array}{c}314(44.2 \% \\
)\end{array}$ & $\begin{array}{c}397(55.8 \% \\
)\end{array}$ & 21 & 50 & $\begin{array}{c}4.29 \\
9\end{array}$ & 33.00 & 32.91 & 4 \\
\hline
\end{tabular}

It may concluded that, according to the overall mean value of awareness computed, 'Net book/Laptop', 'Mobile Phone/I Phone' and 'Desktop' have got the first three ranks respectively and hence, it could be presumed that the strength of awareness is very high for these products.

'Printer/Scanner/Fax Machine', 'Calculator' and 'Projector' have got the last three ranks respectively and hence, it could be presumed that the strength of awareness is very low

It may concluded that, according to the overall mean value of awareness computed, 'Television', 'I Pod' and 'Home Theatre' have got the first three ranks respectively and hence, it could be presumed that the strength of awareness is very high for these products.

'DVD Player', 'Photo Frame' and 'Camera' have got the last three ranks respectively and hence, it could be presumed that the strength of awareness is very low for these products.

for these products.

TABLE - 14

COMPARATIVE STATEMENT OF REACH OF DOMESTIC UTILITY PRODUCTS [ALL BRANDS]

\begin{tabular}{|c|c|c|c|c|c|c|c|c|c|}
\hline S. No & Product awareness & Low & High & Min. & Max. & S.D & Median & Mean & Mean Rank \\
\hline 1. & Refrigerator & $368(51.8 \%)$ & $343(48.2 \%)$ & 22 & 46 & 6.150 & 34.00 & 34.19 & 7 \\
\hline 2. & Air Conditioner & $357(50.2 \%)$ & $354(49.8 \%)$ & 18 & 50 & 6.297 & 35.00 & 35.82 & 2 \\
\hline 3. & Washing Machine & $324(45.6 \%)$ & $387(54.4 \%)$ & 19 & 50 & 6.253 & 36.00 & 35.48 & 3 \\
\hline 4. & Microwave Oven & $358(50.4 \%)$ & $353(49.6 \%)$ & 19 & 46 & 5.437 & 33.00 & 33.32 & 9 \\
\hline 5. & Dish washer & $345(48.5 \%)$ & $366(51.5 \%)$ & 21 & 46 & 5.245 & 33.00 & 32.94 & 10 \\
\hline 6. & Induction Cooker & $367(51.6 \%)$ & $344(48.4 \%)$ & 18 & 50 & 6.974 & 37.00 & 37.95 & 1 \\
\hline 7. & Cloth Dryer & $371(52.2 \%)$ & $340(47.8 \%)$ & 16 & 46 & 5.752 & 34.00 & 34.59 & 5 \\
\hline 8. & Chimney & $338(47.5 \%)$ & $373(52.5 \%)$ & 17 & 47 & 6.903 & 35.00 & 34.49 & 6 \\
\hline 9. & Hob & $385(54.1 \%)$ & $326(45.9 \%)$ & 17 & 48 & 6.090 & 34.00 & 34.82 & 4 \\
\hline 10. & Commercial Laundry & $386(54.3 \%)$ & $325(45.7 \%)$ & 17 & 48 & 6.869 & 33.00 & 34.04 & 8 \\
\hline
\end{tabular}

'Refrigerator', 'Commercial Laundry', 'Microwave Oven' and 'Dish It may concluded that, according to the overall mean value Wfisher' have got the last five ranks respectively and hence, it could awareness computed, 'Induction Cooker', 'Air conditiondre, presumed that the strength of awareness is very low of these 'Washing Machine', 'Hob' and 'Cloth Dryer' have got the first fproducts.

ranks respectively and hence, it could be presumed that the strength of awareness is very high for these products. 'Chimney', 
TABLE - 15

COMPARATIVE STATEMENT OF REACH OF IT AND COMMUNICATION PRODUCTS, ENTERTAINMENT PRODUCTS AND DOMESTIC UTILITY PRODUCTS

[ALL BRANDS]

\begin{tabular}{|c|c|c|c|c|c|c|c|c|c|}
\hline $\begin{array}{l}\mathrm{S} . \\
\mathrm{No} \\
1 \\
2\end{array}$ & $\begin{array}{l}\text { Prod act amaresess } \\
\text { Met book / L apoop } \\
\text { Toleviaion }\end{array}$ & $\begin{array}{l}\text { Low } \\
332(45.796) \\
321(45.196)\end{array}$ & $\begin{array}{l}\text { High } \\
379(53.396) \\
390(549 \%) \\
\end{array}$ & $\begin{array}{l}\text { Mfra. } \\
23 \\
21 \\
\end{array}$ & $\begin{array}{l}\operatorname{Max} \\
50 \\
46 \\
\end{array}$ & $\begin{array}{l}\text { S.D } \\
5.926 \\
4.137 \\
\end{array}$ & $\begin{array}{r}\text { Median } \\
41.00 \\
36.00 \\
\end{array}$ & $\begin{array}{l}\text { Mean } \\
40.73 \\
35.42 \\
\end{array}$ & $\begin{array}{c}\text { Mfon } \\
\text { Ranl } \\
1 \\
3 \\
\end{array}$ \\
\hline 3. & $\begin{array}{l}\text { Mobillo Phonel } \\
\text { Phoes }\end{array}$ & $352(49.596)$ & $359(50.5 \% 6)$ & 20 & 47 & 5.231 & 39.00 & 38.05 & 2 \\
\hline $\begin{array}{l}4 . \\
5 . \\
\end{array}$ & $\begin{array}{l}\text { Tabiet I Pad } \\
\text { I Pod }\end{array}$ & $\begin{array}{l}415(58.4 \% 6) \\
362(50.9 \% 6)\end{array}$ & $\begin{array}{l}296(41.6 \%) \\
349(49.196) \\
\end{array}$ & $\begin{array}{l}21 \\
15\end{array}$ & $\begin{array}{l}48 \\
50\end{array}$ & $\begin{array}{l}5.762 \\
7.212 \\
\end{array}$ & $\begin{array}{l}35.00 \\
34.00\end{array}$ & $\begin{array}{l}3.5 .06 \\
34.53\end{array}$ & $\begin{array}{l}5 \\
12 \\
\end{array}$ \\
\hline $\begin{array}{l}6 . \\
7\end{array}$ & $\begin{array}{l}\text { Memoery Card } \\
\text { Deuts top }\end{array}$ & $\begin{array}{l}423(59.596) \\
370(5296)\end{array}$ & $\begin{array}{l}258(40.596) \\
341(4596)\end{array}$ & $\begin{array}{l}14 \\
20\end{array}$ & $\begin{array}{l}50 \\
50\end{array}$ & $\begin{array}{l}6.723 \\
6.566\end{array}$ & $\begin{array}{l}34.00 \\
3.00\end{array}$ & $\begin{array}{l}34.75 \\
36.23\end{array}$ & $\begin{array}{l}10 \\
4\end{array}$ \\
\hline s. & $\begin{array}{l}\text { Printer/'Sasnner? } \\
\text { FaxMaxhine }\end{array}$ & $355(49996)$ & $356(90.196)$ & 21 & 50 & 7.261 & 34.00 & 33.90 & 16 \\
\hline 9. & Caloulator & $369(51996)$ & $342(43.1 \%)$ & 17 & 45 & 7.274 & 3200 & 3299 & 19 \\
\hline $\begin{array}{l}10 . \\
11 .\end{array}$ & $\begin{array}{l}\text { Hoems Thedire } \\
\text { Photo I name }\end{array}$ & $\begin{array}{l}352(49.596) \\
393(55.396)\end{array}$ & $\begin{array}{l}359(30.596) \\
319(44.796)\end{array}$ & 22 & $\begin{array}{l}43 \\
45\end{array}$ & $\begin{array}{l}4.559 \\
7.678\end{array}$ & $\begin{array}{l}34,00 \\
32.00\end{array}$ & $\begin{array}{l}33.29 \\
32.63\end{array}$ & $\begin{array}{l}13 \\
23\end{array}$ \\
\hline 12. & Projectos & $456(64-196)$ & $255(35996)$ & 18 & 43 & 6912 & 30.00 & 31.05 & 25 \\
\hline $\begin{array}{l}13 . \\
14 .\end{array}$ & $\begin{array}{l}\text { DVD Pl ayer } \\
\text { Camera }\end{array}$ & $\begin{array}{l}394(55.496) \\
408(57.496)\end{array}$ & $\begin{array}{l}317(44.696) \\
303(42.696)\end{array}$ & $\begin{array}{l}18 \\
17 \\
\end{array}$ & $\begin{array}{l}45 \\
50 \\
\end{array}$ & $\begin{array}{l}3.058 \\
7.508 \\
\end{array}$ & $\begin{array}{l}31.00 \\
31.00 \\
\end{array}$ & $\begin{array}{l}32.34 \\
31.32 \\
\end{array}$ & 24 \\
\hline 15. & Rofrigeratod & $368(51.396)$ & $343(43296)$ & 22 & 45 & 6.150 & 34.00 & 34.19 & 14 \\
\hline $\begin{array}{l}16 . \\
17\end{array}$ & $\begin{array}{l}\text { AirCondi tionser } \\
\text { Washing Madhine }\end{array}$ & $\begin{array}{l}357(50.296) \\
324(45.6 \% 9)\end{array}$ & $\begin{array}{l}354(49.596) \\
357(54.496)\end{array}$ & $\begin{array}{l}18 \\
19\end{array}$ & $\begin{array}{l}50 \\
50\end{array}$ & $\begin{array}{l}6.297 \\
6253\end{array}$ & $\begin{array}{l}3.5 .00 \\
3.00\end{array}$ & $\begin{array}{l}3.5 .52 \\
35.48\end{array}$ & $\frac{6}{7}$ \\
\hline 18. & Marartive Oven & $358(50.4 \% 6)$ & $353(49.696)$ & 19 & 45 & 5.437 & 33.00 & 33.32 & 17 \\
\hline $\begin{array}{l}19 . \\
20 . \\
21\end{array}$ & $\begin{array}{l}\text { Diah weher } \\
\text { Lodresion Codk ox } \\
\text { Cloth Dryex }\end{array}$ & $\begin{array}{l}345(43 \quad 596) \\
367(51.696) \\
371(52296)\end{array}$ & $\begin{array}{l}366(31.596) \\
344(43.496) \\
340(47.396)\end{array}$ & $\begin{array}{l}21 \\
13 \\
16\end{array}$ & $\begin{array}{l}45 \\
50 \\
45\end{array}$ & $\begin{array}{l}5.245 \\
6.974 \\
5.752\end{array}$ & $\begin{array}{l}33.00 \\
37.00 \\
34.00\end{array}$ & $\begin{array}{l}3294 \\
3795 \\
3459\end{array}$ & $\begin{array}{l}20 \\
3 \\
11\end{array}$ \\
\hline$\frac{22}{23}$ & $\begin{array}{l}\text { Chimmoy } \\
\text { Hob }\end{array}$ & $\begin{array}{l}335(47.596) \\
355(54.1 \% 6)\end{array}$ & $\begin{array}{l}373(52596) \\
326(45996)\end{array}$ & $\begin{array}{l}17 \\
17\end{array}$ & $\begin{array}{l}47 \\
43\end{array}$ & $\begin{array}{l}6.903 \\
6.090\end{array}$ & $\begin{array}{l}35.00 \\
34.00\end{array}$ & $\begin{array}{l}34.49 \\
34.32\end{array}$ & $\begin{array}{l}13 \\
9\end{array}$ \\
\hline 24. & $\begin{array}{l}\text { Coemmercial } \\
\text { Lumeng }\end{array}$ & $396(54.396)$ & $325(45.7 \%)$ & 17 & 48 & 6.569 & 33.00 & 34.04 & 15 \\
\hline 25. & Cemoorde & $314(44296)$ & $397(55.596)$ & 21 & 50 & 4299 & 33.00 & 3291 & 21 \\
\hline & $\begin{array}{l}\text { Ovonlil Prodset } \\
\text { Awaroses }\end{array}$ & $375(527 \% 9)$ & $336(47.396)$ & 579 & 1094 & 97.076 & 35200 & 964.94 & - \\
\hline
\end{tabular}

It may concluded that, according to the overall mean value of awareness computed, 'Net book/Laptop', 'Mobile Phone/I Phone', 'Induction Cooker', 'Desktop' and 'Tablet/I Pad' have got the first five ranks respectively and hence, it could be presumed that the strength of awareness is very high for these products.

'Camcorder', 'DVD Player', 'Photo Frame', 'Camera' and 'Projector' have got the last five ranks respectively and hence, it could be presumed that the strength of awareness is very low of these products.

\section{Results of the test of hypothesis}

There is a significant difference between gender, UG qualification, districts of the respondents and their overall awareness on extended brands. Hence, the null hypothesis is rejected.

There is a significant difference between gender, UG qualification, districts of the respondents and their overall awareness on the products of extended brands. Hence, the null hypothesis is rejected.

There is no significant difference between family monthly income, family monthly expenses of the respondents and their overall awareness on extended brands. Hence, the null hypothesis is accepted.

There is no significant difference between family monthly income, family monthly expenses of the respondents and their overall awareness on the products of extended brands. Hence, the null hypothesis is accepted.

There is no significant association between age of the respondents and their overall awareness on extended brands. Hence the null hypothesis is accepted.
There is no significant association between age of the respondents and their overall awareness on the products of extended brands. Hence, the null hypothesis is accepted.

\section{RESULTS OF INDEX VALUE OF AWARENESS OF EXTENDED BRANDS}

TABLE - 16

INDEX VALUE OF THE AWARENESS OF FOREIGN BRANDS [ALL PRODUCTS]

\begin{tabular}{|c|c|c|c|}
\hline S. No & BRAND NAME & INDEX VALUE & RANK \\
\hline 1. & Intel & 1064.321 & 5 \\
\hline 2. & Apple & 1254.783 & 2 \\
\hline 3. & HP & 1075.685 & 4 \\
\hline 4. & Samsung & 1288.680 & 1 \\
\hline 5. & Canon & 1165.697 & 3 \\
\hline
\end{tabular}

Source: Field Data

It may concluded that, according to the overall index value of awareness computed, 'Samsung', 'Apple' and 'Canon' have got the first three ranks respectively and hence, it could be presumed that the strength of awareness is very high for these brands.

'HP' and 'Intel' have got the last two ranks respectively and hence, it could be presumed that the strength of awareness is very low for these brands.

\section{RESULTS OF INDEX VALUE OF AWARENESS OF PRODUCTS OF EXTENDED BRANDS}

TABLE - 17

INDEX VALUE OF THE AWARENESS OF IT AND COMMUNICATION PRODUCTS [ALL BRANDS]

\begin{tabular}{|c|l|c|c|}
\hline S. No & \multicolumn{1}{|c|}{ PRODUCT NAME } & INDEX VALUE & RANK \\
\hline 1. & Net Book/Laptop & 670.431 & 1 \\
\hline 2. & Mobile Phone/I Phone & 591.530 & 2 \\
\hline
\end{tabular}




\begin{tabular}{|l|l|l|l|}
\hline 3. & Tablet/I Pad & 518.673 & 3 \\
\hline 4. & Memory Card & 449.868 & 5 \\
\hline 5. & Desktop & 514.173 & 4 \\
\hline 6. & Printer/Scanner/Fax Machine & 430.430 & 6 \\
\hline 7. & Calculator & 406.801 & 7 \\
\hline 8. & Projector & 342.498 & 8 \\
\hline
\end{tabular}

Source: Field Data.

It may concluded that, according to the overall index value of awareness computed, 'Net Book/Laptop', 'Mobile Phone/I Phone' and 'Tablet/I Pad' have got the first three ranks respectively and hence, it could be presumed that the strength of awareness is very high for these products.

Calculator' and 'Projector' have got the last two ranks respectively and hence, it could be presumed that the strength of awareness is very low for these products.

TABLE - 18

INDEX VALUE OF THE AWARENESS OF ENTERTAINMENT PRODUCTS [ALL BRANDS]

\begin{tabular}{|c|l|c|c|}
\hline S. No & PRODUCT NAME & INDEX VALUE & RANK \\
\hline 1. & Television & 514.115 & 1 \\
\hline 2. & I Pod & 477.802 & 2 \\
\hline 3. & Home Theatre & 434.145 & 3 \\
\hline 4. & Photo Frame & 403.286 & 5 \\
\hline 5. & DVD Player & 425.761 & 4 \\
\hline 6. & Camera & 397.828 & 6 \\
\hline 7. & Camcorder & 353.160 & 7 \\
\hline
\end{tabular}

Source: Field Data.

It may concluded that, according to the overall index value of awareness computed, 'Television', 'I Pod' and 'Home theatre' have got the first three ranks respectively and hence, it could be presumed that the strength of awareness is very high for these products.

'Camera' and 'Camcorder' have got the last two ranks respectively and hence, it could be presumed that the strength of awareness is very low for these products.

TABLE - 19

INDEX VALUE OF THE AWARENESS OF DOMESTIC UTILITY PRODUCTS [ALL BRANDS]

\begin{tabular}{|c|l|c|c|}
\hline S. No & PRODUCT NAME & INDEX VALUE & RANK \\
\hline 1. & Refrigerator & 448.152 & 3 \\
\hline 2. & Air Conditioner & 498.843 & 1 \\
\hline 3. & Washing Machine & 493.967 & 2 \\
\hline 4. & Microwave Oven & 415.269 & 9 \\
\hline 5. & Dish Washer & 387.731 & 10 \\
\hline 6. & Induction Cooker & 429.587 & 5 \\
\hline 7. & Cloth Dryer & 427.140 & 7 \\
\hline 8. & Chimney & 433.612 & 4 \\
\hline 9. & Hob & 429.447 & 6 \\
\hline
\end{tabular}

Source: Field Data.

It may concluded that, according to the overall index value of awareness computed, 'Air Conditioner', 'Washing Machine', 'Refrigerator', 'Chimney' and 'Induction Cooker' have got the first five ranks respectively and hence, it could be presumed that the strength of awareness is very high for these products.

'Hob', 'Cloth Dryer', 'Commercial Laundry', 'Microwave Oven' and 'Dish Washer' have got the last five ranks respectively and hence, it could be presumed that the strength of awareness is very low for these products.
TABLE - 20

INDEX VALUE OF THE AWARENESS OF IT AND COMMUNICATION PRODUCTS, ENTERTAINMENT PRODUCTS AND DOMESTIC UTILITY PRODUCTS

[ALL BRANDS]

\begin{tabular}{|c|l|c|c|}
\hline S. No & \multicolumn{1}{|c|}{ PRODUCT NAME } & INDEX VALUE & RANK \\
\hline 1. & Net Book/Laptop & 670.431 & 1 \\
\hline 2. & Television & 514.115 & 5 \\
\hline 3. & Mobile Phone/I Phone & 591.530 & 2 \\
\hline 4. & Tablet/I Pad & 518.673 & 3 \\
\hline 5. & I Pod & 477.802 & 8 \\
\hline 6. & Memory Card & 449.868 & 9 \\
\hline 7. & Desktop & 514.173 & 4 \\
\hline 8. & Printer/Scanner/Fax Machine & 430.430 & 13 \\
\hline 9. & Calculator & 406.801 & 20 \\
\hline 10. & Home Theatre & 434.145 & 11 \\
\hline 11. & Photo Frame & 403.286 & 21 \\
\hline 12. & Projector & 342.498 & 25 \\
\hline 13. & DVD Player & 425.761 & 17 \\
\hline 14. & Camera & 397.828 & 22 \\
\hline 15. & Refrigerator & 448.152 & 10 \\
\hline 16. & Air Conditioner & 498.843 & 6 \\
\hline 17. & Washing Machine & 493.967 & 7 \\
\hline 18. & Microwave Oven & 415.269 & 19 \\
\hline 19. & Dish Washer & 387.731 & 23 \\
\hline 20. & Induction Cooker & 429.587 & 14 \\
\hline 21. & Cloth Dryer & 427.140 & 16 \\
\hline 22. & Chimney & 433.612 & 12 \\
\hline 23. & Hob & 429.447 & 15 \\
\hline 24. & Commercial Laundry & & 18 \\
\hline
\end{tabular}

Source: Field Data

It may concluded that, according to the overall index value of awareness computed, 'Net book/Laptop', 'Mobile Phone/I Phone', 'Tablet/I Pad', 'Desktop' and 'Television' have got the first five ranks respectively and hence, it could be presumed that the strength of awareness is very high for these products.

'Photo Frame', 'Camera', 'Dish Washer', 'Camcorder' and 'Projector' have got the last five ranks respectively and hence, it could be presumed that the strength of awareness is very low for these products.

\section{SUGGESTIONS}

The companies should try to use the strategy of brand extension to offer as many varieties of products to the customers as possible. The variety offered through brand extension will definitely retain the customers within the fold of one brand. When the customers stay with a brand for a long time, their level of awareness on the main and especially on the extended brands will improve.

Brand extension, as a strategy, should be used more as means of offering useful products to the public than as a strategy to increase the profit of the company. The higher the use of a product of the extended brand, the longer will the stay of the customer with the brand. This will definitely improve the brand equity.

Brand extension should be done in such a way that a customer should feel it easy to transfer his knowledge about the main brand to the extended brands and products. The highly technical features of the extended brand should not

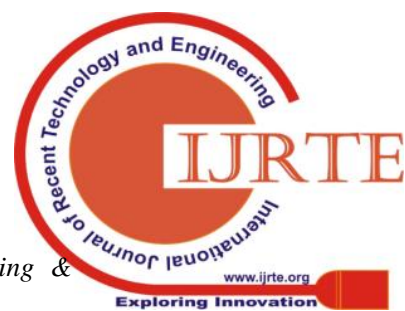


derail the understanding of customers on the original brand.

An extended brand should be used by the company to reduce the perceived risk of customers on the main and extended brand. Complication or confusion in this regard may increase the level of perceived risk and may hamper the marketing initiatives of the companies.

The reduction of cost of developing a new brand and that of marketing it resulted by the extension of brand, if passed on to the customers as promotional offers, will serve as an extra attraction that will force customers to learn more about the extended brands.

The companies must strike a balance between the conventional and modern media for advertising to create awareness for their extended brands because still there are millions of people around the world who read newspapers, journals, magazines, etc.,

The companies are sponsoring public events/reality shows/charity programmes to create awareness on their extended brands. It would be better if they concentrate on the products of their extended brands. They can prominently display their products, besides their brands to make their brand extension more effective.

The companies, at their Point of Sales [POS], can combine modern techniques and technologies to display the products of their extended brands.

\section{CONCLUSION}

Brand Extension is the use of an established brand name in new product categories. This new category to which the brand is extended can be related to the existing product categories. A renowned/successful brand helps an organization to launch products in new categories more easily.

Reduction of the risk perceived by customers, reduction in the promotional expenditure and reduction of the cost of developing a new brand are the benefits of Brand Extension.

The reach of Brand Extension has been found to be satisfactory and the level of awareness on Foreign Brands.

Brand Extension should be used to improve the CSR capability of the company besides being to enhance the marketing and the profitability of the company.

\section{REFERENCES}

1. Pitta Dennis A and Katsanis Lea Prevel (1995), Understanding Brand Equity for Successful Brand Extension, Journal of Consumer Marketing, Vol. 12(4), pp.51-64.

2. Aaker D.A. and Keller K.L. (1990), Consumer Evaluations of Brand Extensions, Journal of Marketing, Vol. 54(1), pp. 27-41.

3. Tauber E.M. (1981), Brand Franchise Extension: New Product Benefits from Existing Brand Names, Business Horizons, Vol. 24(2), pp. 36-41.

4. Tariq Jalees and Dr. Tahir Ali, How do consumers evaluate brand-extensions a five-factor approach, Market forces, July-2008, pp. 09-17.

5. Buday, T. (Fall 1989). Capitalization on Brand Extensions. The Journal of Consumer Marketing 6(4), 27.

6. Styles, T.A. a.c. (1997). Brand development versus new product development: toward a process model of extension decisions Journal of Product \& brand Management, 6(4), 222-234.

7. Building Brand Value by M.G. Parameswaran (first edition 2006), Tata McGraw Hill Publication Company Limited, New Delhi; pp: 241, 243.
8. Building Brands in the Indian Market ( $1^{\text {st }}$ Edition), "Familiarity Breeds Profits-Brand Extension strategies in India" 2008 by N. Thamaraiselvan; Anurag Jain for excel Books, New Delhi; Pp. 230-231.

9. Building Brands in the Indian Market ( $1^{\text {st }}$ Edition), "Creeping Extensions" 2008 by S. Sakthivel Rani, Anil C, A. Seethalakshmi; Anurag Jain for excel Books, New Delhi; Pp. 260 - 263.

10. Babu John Mariadoss, Raj Echambadi, Mark J. Arnold \& Vishal Bindroo (2010), An examination of the effects of perceived difficulty of manufacturing the extension product on brand extension attitudes, Journal of Academy of Marketing Science, No. 38, pp.704-719.

11. Vicki Lane and Robert Jacobson (1997), The Reciprocal Impact of Brand Leveraging: Feedback Effects from Brand Extension Evaluation to Brand Evaluation, Marketing Letters, Vol. 8, No.3, pp.261-271.

12. Devon Del Vecchio and Daniel C. Smith (2005), Brand-Extension Price Premiums: The Effects of Perceived Fit and Extension Product Category Risk, Journal of Academy of Marketing Science, Vol. 33, No. 2, pp.184-196.

13. Wilfried R. Vanhonacker (2007), Brand Extension Naming Strategies: An Exploratory Study of the Impact of Brand Traits, Marketing Letters, Vol. 18, pp.61-72.

14. Valerie A. Taylor and William O. Bearden (2002), The Effects of Price on Brand Extension Evaluations: The Moderating Role of Extension Similarity, Journal of Academy of Marketing Science, Vol. 30, No. 2, pp.131-140.

15. Fu Guoqun and Ding Jiali (2002), Ownership effects in consumers' brand extension evaluations, Front Business Research China, Vol. 1, No. 2, pp. 193-210.

16. Nathalie Dens and Patrick De Pelsmacker (2010), Advertising for extensions: Moderating effects of extension type, advertising strategy, and product category involvement on extension evaluation, Marketing Letters, Vol. 21, pp.175-189.

17. Michael S. Mccarthy, Timothy B. Heath and Sandra J. Milberg (2001), New Brands versus Brand Extensions, Attitudes versus Choice: Experimental Evidence for Theory and Practice, Marketing Letters, Vol. 12, No. 1, pp.75-90.

18. Duncan B. Milloy (2007), The Effect of Favorable Usage Experience with a Core Brand on Core Brand Extension Perception and Purchase Intention, A Dissertation Presented to the Faculty of the College of Business Administration of Touro University International, pp. 1-136.

19. Swaminathan, V.F., R.J. and Reddy, (2001), The Impact of Brand Extension Introduction on Choice, Journal of Marketing, 65 (October), pp. $1-15$.

20. Catherine W.M. Yeung and Robert S. Wyer JR. (2005), Does Loving a Brand Mean Loving Its Products? The Role of Brand-Elicited Affect in Brand Extension Evaluations, Journal of Marketing Research, Vol. XLII, pp. 495-506.

21. Franziska Volckner and Henrik Sattler (2006), Drivers of Brand Extension Success, Journal of Marketing, Vol. 70, pp. 18-34.

22. Alokparna Basu Monga Deborah Roedder John (2007), Cultural Differences in Brand Extension Evaluation: The Influence of Analytic versus Holistic Thinking, Journal of Consumer Research, Vol. 33, pp.529-536.

23. Henrik Sattler, Franziska Völckner, Claudia Riediger, Christian M. Ringle, The Impact of Brand Extension Success Drivers on Brand Extension Price Premiums, Forthcoming IJRM, Vol. 27, pp. 1-37.

24. Deborah Roedder John, Barbara Loken, and Christopher Joiner (1998), The negative impact of extensions: Can flagship products be diluted?, Journal of Marketing, Vol. 62, Pp.19-32.

25. Jose M. Pina, Eva Martinez, Leslie de Chernatony and Susan Drury, (2006) "The effect of service brand extension on corporate image: An empirical model", European Journal of Marketing, Vol. 40 Issue: 1/2, Pp. 174-197.

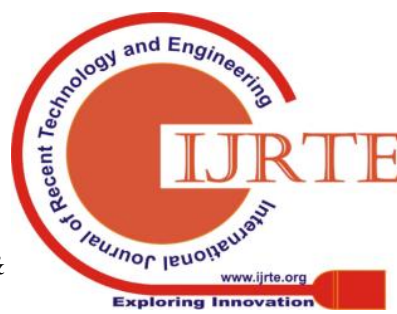

